\title{
THE ANALYSIS ON BACKGROUND, ORGANIZING PRINCIPLE, AND TYPE OF SYLLABUS ON ENGLISH COURSEBOOK ENGLISH IN FOCUS
}

\author{
Imam Munandar \\ IAIN Takengon, Aceh Tengah, Aceh \\ Email: imameducator@gmail.com
}

\begin{abstract}
This research tries to look closely at the background, organizing principle, and how the English in Focus coursebook is designed. To figure out the answer, the research employs a qualitative study with a descriptive approach. The book itself is analyzed by using three parameters set by Canale and Swain, namely 1 . The background, 2.Organizing principle, and 3.Type of the syllabus. The research has found that the book is designed to be used in a target-removed context in the EFL context. Furthermore, the book follows the functional/notional syllabus. The conceptualization of language is designed to follow communicative functions, incorporating Canale and Swain's language model involving linguistic, discourse socio-cultural, and strategic components. Following that, the book integrates other syllabus strands. The functional approach is shown by different language functions presented to students, while the discourse syllabus is realized in the speech acts involving politeness and formal and informal language. The structural syllabus is indicated by the grammar items to be learned by students inductively. However, some issues should be addressed in the book. The strategic competence that underlies the syllabus is limitedly realized in the classroom activities. In this case, the books should consider the tasks that enable students to develop their skills in avoiding communication breakdowns such as turn-taking and repair.
\end{abstract}

Keywords: English Language Syllabus, Critical Analysis, English Language Education

\begin{abstract}
Abstrak: Penelitian ini mencoba mencermati latar belakang, prinsip pengorganisasian, dan bagaimana buku mata pelajaran English in Focus dirancang.Untuk mencari jawabannya, penelitian ini menggunakan studi kualitatif dengan pendekatan deskriptif, dengan menggunakan instrument yang sudah di tetapkan oleh Swain dan Canale.Buku itu sendiri dianalisis dengan menggunakan tiga parameter, yaitu 1.Latar belakang, 2. Prinsip pengorganisasian, dan 3. Jenis silabus. Penelitian telah menemukan bahwa buku tersebut dirancang untuk digunakan dalam konteks penghapusan target dalam konteks EFL. Selanjutnya buku mengikuti silabus fungsional / nosional.Konseptualisasi bahasa di dirancang untuk mengikuti fungsi komunikatif, yang menggabungkan model bahasa Canale dan Swain yang melibatkan komponen linguistik, wacana sosio kultural, dan strategis. Setelah itu, buku tersebut mengintegrasikan untaian silabus lainnya.Pendekatan fungsional ditunjukkan dengan perbedaan fungsi bahasa yang disajikan kepada siswa, sedangkan silabus wacana diwujudkan dalam tindak tutur yang melibatkan kesantunan dan bahasa formal dan informal.Silabus structural ditandai dengan materi tata bahasa yang dipelajari siswa secara induktif.Namun, ada beberapa masalah yang harus dibahas dalam buku ini.Kompetensi strategis yang mendasari silabus terwujud secara terbatas dalamkegiatan kelas.Dalam hal ini, buku harus mempertimbangkan tugas-tugas yang memungkinkan siswa mengembangkan keterampilannya dalam menghindari gangguan komunikasi seperti pengambilan giliran dan perbaikan.
\end{abstract}

Kata Kunci: Silabus Bahasa Inggris, Analisis Kritis, Pendidikan Bahasa Inggris

\section{INTRODUCTION}

The significant changes in the language conceptualization have influenced the planning and designing of the syllabus for language teaching, especially those designed to teach English as a second language (Nunan \& Lamb, 2001). Communicative language 
teaching (CLT) attempts to supply sufficient attention to language use and language form (Breen \& Candlin, 2001). Graves (2008) explains some types of syllabuses operating within the CLT curriculum, namely the Functional/ notional, Task-Based, and ContentBased syllabus. Unlike the formal syllabus, which is only devoted to language in form, these syllabuses share common objectives and components as they are designed to fulfill the learners' needs by focusing on language in use (McKay, 2003).

The Functional/Notional syllabus is the syllabus that conceptualizes language as a system of expression of meaning as a means of real-world communication, and it is organized around communicative functions (Richards, 2001). The language learning focus rests on the use of language for various functions. It is proposed after the formal syllabus's perceived failure to use linguistic competence outside the classroom (Breen, 2001). Unlike the Formal syllabus, which greatly considers the language's grammatical focus, this syllabus is designed to expose the learner to language use in real-world situations. The language model on which this syllabus is based is the conceptualization that sees language in terms of linguistic elements and other communicative performance components such as pragmatics and strategic knowledge (Bloor, 2004).

The Task-Based syllabus is considered the extreme manifestation of the CLT curriculum in which it considers very few linguistic components in its content, which results in minimizing the knowledge of the language (Ellis, 2002). As Graves (2008: 152) explains, the central characteristic of this syllabus is that it treats language as a means of accomplishing classroom activities. This syllabus is seen as a process-oriented syllabus since it emphasizes the process of how learners learn the language, rather than the linguistic product of what they have learned.

Another type of syllabus within CLT is the Content-based syllabus. This syllabus is usually designed to teach English not as a subject, but as a medium through which the other skills are taught (Lin, 2002). Content is the starting point in this syllabus design (Richards, 2001). Graves (2008) explains that besides becoming the means for carrying out tasks or using language, a Content-Based syllabus facilitates the learner to learn new content. This syllabus is usually found in bilingual schools, in which English as L2 is a means of communication and a class instruction language in learning other knowledge areas such as science, math, physics, etcetera. (Burn, 2001).

Following the syllabus description above, the syllabus can be seen as a systematic plan of action and content enacted in the classroom to attain the pre-determined goal of a 
particular program. It is thus important to consider the definition raised by Long, Richards, and Crookes (as cited in the Study Guide, 2010: 3), who define syllabus as "the elements of the target language and how they should be presented.". Also, Nunan's definition is useful to understand the syllabus, for which he says "the specification of the content of the course and the order in which that content will be taught" (Nunan, 1988, as cited in Graves, 2008:159).

\section{LITERATURE REVIEW}

The syllabus under this analytical research is in the form of a textbook titled " ENGLISH IN FOCUS. It is a book for the first-year students of secular and Islamic Junior high schools in Indonesia. The book has been assessed and standardized by the Ministry of Education of Indonesia and has met the criteria for use in Indonesian schools. The government has bought the patent of the book from the author, and it can be reproduced freely and for educational purposes. The book is one of the three series of textbooks specifically designed for Grade One until Grade Three of junior high schools. It consists of eight units (chapters) and is packaged with an audio cassette for listening comprehension focus.

In term of syllabus organization, the book is organized around functional/ notional principle because it mainly considers functional aspects of the language. Richards (2001) defines a functional syllabus as a syllabus that is organized around the communicative function. The syllabus's functional principle in the book is shown by communicative competence in authentic and real-world situations. In each book unit, the communicative functional themes are presented to students, including greeting, expressing apology and gratitude, asking for information, expressing command and prohibition, expressing politeness, asking and giving an opinion, expressing like and dislike, asking and giving facts, and asking for clarification. These themes show that the focus of the syllabus is on the communicative function of language.

The syllabus's conceptualization of the syllabus follows Canale and Swain's language model, which involves linguistic, sociolinguistic, strategic, and discourse competence. Following the language model it adheres to, the book integrates other syllabus strands, including discourse, structural, and text-based syllabus. The book's discourse-based discourse is realized in the form of speech acts that consider sociocultural and strategic competence operating in the target language situation (McCarthy \& 
Carter, 2001). This discourse syllabus integration can be traced in the book when students are presented with the culturally appropriate way of asking and commanding by using please, could you, and formal and informal ways of speaking regarding the listeners' ages by using, for example, good morning versus $\mathrm{Hi}$.

Furthermore, the reading and writing sections are organized around a text-based approach. Text-based syllabus sees the language as "a whole text that is embedded in social contexts, created and used by people for different purposes" (Graves, 2008: 161). Besides focusing on pronunciation, stress, intonation, and identifying meaning, these skills are functionally presented in different text genres such as descriptive, short text, and functional text such as advertisement. Furthermore, the writing section introduces students to different writing genres, such as descriptive, functional, and procedural text, and enables them to write differently in different genres (Fulcher, 2007).

The structural approach into the syllabus, the book introduces a grammar lesson presented at every unit's end (Harmer, 2007). The grammatical approach is organized around grammatical items of the language (Richards, 2001). As in previously mentioned skills, grammar, which is presented functionally, is learned inductively. From a given chunk, students learn particular grammatical features involved in the chunk. The grammar remains an important aspect to consider in the book since it enables students to practice with grammatical components of the language, which will be tested in the national examination by the end of the school year.

The syllabus can be considered an analytical syllabus, which can be deduced from how the contents are presented. An analytical syllabus presents students with holistic examples of language that they analyze to induce the constituent parts (Wilkin, 1967, as cited in Lewis, 2001). In the book, the students are first introduced to an example of daily conversation, and students are taught to identify words used for politeness such as please, would you, and several expressions in responding to gratitude such as thanks, you are welcome, and etcetera. Also, grammar items to be learned are taken from chunks of the language that have communicative functions.

\section{RESEARCH METHODOLOGY}

This research tries to look closely at the background, organizing principle, and how the English in Focus coursebook is designed. To figure out the answer, the research employs a qualitative study with a descriptive approach. The book itself is analyzed by 
using three analysis criteria introduced by Swain and Canale. These criteria are 1. the background, 2. organizing principle, and 3.type of the syllabus.

\section{FINDINGS AND DISCUSSION}

\section{Language-Focused Syllabus of the Book}

Language is seen as a product of language learning. Classroom activities are set out as a means that results in language learning (Graves, 2008). There is a pre-selected kind of language in this syllabus to be taught, for example, typical language used in first-time encounters/ introductions. In the reading and writing section, there are several preselected skills that students hope to acquire, such as reading with proper intonation, pronunciation, stress, identifying particular genres of text, and producing a text-based on a particular genre. In the grammar section, there are grammatical items that students are expected to master as the outcome of the lesson, for example, items like tobe, using there $i s$ versus there are, preposition, etcetera. It is not learning-focused because it does not consider teaching students how to learn a language; there is little focus on the processes through which learning takes place. As well, it is not content-focused since it does not teach new knowledge content. The contents are around everyday life topics, which are very general and familiar to students. These pre-selected language components show that the syllabus has language objectives to be acquired by students due to classroom learning activities (Taylor, 2005).

The authors' preference of the language-focus syllabus in their books addresses the conceptualization of language learning that sees language as a product, which is taught and tested (Freeman, 1998). Like any other subjects such as math and biology, English is taught as an independent subject in school. The book is designed to focus on the language itself since language competence is tested in language measurement.

\section{Language Learning Component and Organizing Principle Within Units}

Within each unit, the book is organized around the four language skills: listening, speaking, reading, and writing. The units consist of activities and exercises. Take Unit One, for example; in the listening section, the language learning components include language use typically used for greeting. The activities range from listening and repetition, followed by an exercise of fill in the blank. Also, there is a learning activity to pronounce a list of vocabulary selected from the topic. In speaking, the students are presented with the same theme; the language used for greeting. The listen and repetition 
are presented for a speaking model for students and then work in pairs to practice the dialogue based on the presented picture. As an exercise, the students are presented with completing dialogue, which is done in pairs. Students also are required to write a dialogue according to a given situation and act it out. The speaking section also provides students with a selected list of vocabulary to be spelled out correctly.

In reading and writing, the book provides different genres of text for students. In Unit One, reading is concerned with reading for correct pronunciation, stress, and intonation. The activities and exercises include reading aloud, completing the sentence based on the picture, and supplying information in a short text genre. Furthermore, the writing section introduces students to a text genre (greeting card), which is followed by exercises of answering the question related to the greeting card and filling in the blank in another uncompleted greeting card provided. Students are then presented with a list of vocabulary typically used in greeting cards, and in the final stage of the section, the students are required to write a greeting card according to a given situation.

Furthermore, the unit presents some sentences that use the grammatical item to be. Students then are presented with rules on how to be is used inappropriately. After that, a Learning Essential is provided to summarize the focus of language students have learned in the unit-the language functions of greeting and introducing expression and grammar items to be. Besides, the Learning Review is also provided for students to reflect on what students have learned and use the language after learning it within the unit.

\section{The Sequence of the Syllabus of the Book}

According to Hedge (2003), there two types of syllabus organized according to the following sequence. Firstly, in the listening and speaking sections, the syllabus is organized based on need sequence, which focuses on things that students will do with the language use such as introducing him/herself, expressing gratitude, asking opinion, giving an opinion, etc. Richards (2001) explains that in the need sequence of the syllabus, the content may be sequenced according to when learners are most likely to need it outside of the classrooms. This need sequence is based on need analysis conducted before the organization of the book. It is assumed that the language needs of first-year students of junior high schools are those topics which are familiar and fundamental in language use in various everyday situations.

The second sequencing type is simple to the complex sequence. This kind of sequencing applies to reading, writing sections, and grammar focus (Gibbons, 2002). The 
simpler content is presented earlier than later ones (Richard, 2001). In reading and writing, the contents are graded in terms of difficulty, from simple descriptive text such as reading and writing greeting cards reading and writing longer functional and procedural texts such as an advertisement and a recipe on making a particular dish. Similarly, grammatical items are presented in terms of difficulty level. Earlier grammar focuses cover simple grammatical items such as using adjectives and complex ones such as verb-ing and tenses (McNamara, 1998).

There are some valuable aspects of the book for students (Nunan, 2001). It provides content that is familiar to students and responsive to the Indonesian socio-cultural situation. By presenting those familiar and authentic topics, students feel encouraged since they know the purpose of learning English and apply it outside the classroom. For example, the texts presented in the reading are about Indonesian culture found in the students' environment, such as Indonesian food, amazing places in Indonesia, going to Bali, etc. Also, because Indonesian culture addresses people differently in terms of age, Siris is encouraged to be used when addressing the older addressee. Apart from this, speech acts are presented before each speaking section. They are presented in the listening section to inform those speech acts and use them in the following speaking section.

\section{CONCLUSIONS}

The book is designed to be used in a target-removed context in which English is considered a foreign language. The book is organized around the functional/notional syllabus. The book's conceptualization in the book follows communicative functions, which incorporate Canale and Swain's language model involving linguistic, discourse, socio-cultural, and strategic components. Following that, the book integrates other syllabus strands. The functional approach is shown by different language functions presented to students, while the discourse syllabus is realized in the speech acts involving politeness and formal and informal language. The structural syllabus is indicated by the grammar items to be learned by students inductively.

Meanwhile, the text-based syllabus is shown in the different genres of texts presented in the reading and writing sections. Furthermore, the syllabus focuses on the language itself, which sees language competence as the result of learning. Meanwhile, 
each unit's organizing principle follows the four language skills, along with activities and exercises and language production.

However, some issues should be addressed in the book. The strategic competence that underlies the syllabus is limitedly realized in the classroom activities. In this case, the books should consider the tasks that enable students to develop their skills in avoiding communication breakdowns such as turn-taking and repair. Besides, the book also needs to consider the different institutions that will use the book, such as Islamic schools. The pictures presented do not meet Islamic schools' expectations because of the unsuitable dress code presented in the book. Thus, the book needs to consider the different values that different schools maintain.

\section{REFERENCES}

Bloor, T. \& Bloor, M. (2004). The functional analysis of English. London: Hodder Education.

Breen, M. (2001). The Cambridge guide to teaching English to speakers of other languages. London: Cambridge University Press.

Breen, M. P. \&Candlin, C. N. (2001). The essential of a communicative curriculum in language teaching. Oxon: Routledge.

Burn, A. (2001). A genre-Based approach to writing and beginning adult ESL learners. English language teaching in its social context. London: Routledge.

Carless, D. R. (2001). A case study of curriculum implementation in Hong Kong. In DR Hall and A Hewings (Eds.), Innovation in English language teaching. Oxon: Routledge.

Derewianka, B. (2003). Trends and issues in Genre-Based approaches. London: Hodder Education.

Ellis, R. (2002). New perspectives on grammar teaching in second language classrooms. Marwah: Lawrence Erlbaum.

Freeman, Y \& Freeman, D. (1998). ESL/EFL teaching: principles for success. Portsmouth: Heinemann.

Fulcher, G., \& Davidson, F. (2007). Language testing and assessment: an advanced resource book. Abingdon: Routledge.

Gibbons, P. (2002). Scaffolding language, scaffolding learning: teaching second language learners in the mainstream classroom. Portsmouth: Heinemann.

Graves, K. (2008). The language curriculum: a social-contextual perspective. London: Cambridge University Press.

Harmer, J. (2007). The practice of language teaching. Harlow: Pearson Education.

Hedge, T. (2003). Grammar. Teaching and learning in the language classroom. Oxon: Routledge. 
Hill, K. (2009). Self and peer assessment and assessment of young learners. Melbourne: Deakin University.

Kostogriz, A. (2010). Course development process: a summary of week 1-5. Melbourne: Deakin University Press.

Lewis, M. (2001). Lexis in the syllabus. Oxon: Routledge.

Lin, B. (2002). English as an international language: discourse as an answer to what to teach \& how to teach it. Conference Proceeding of The 7th Annual Conference Pan-Pacific Association of Applied Linguistics.1-16.

https://www.academia.edu/4052710/english_as_an_international_language_discour se_as_an_answer_to_what_to_teach_and_how_to_teach_it

Markee, N. (2001). The diffusion of innovation in language teaching. In DR Hall and A Hewings (Eds.), Innovation in English language teaching. Oxon: Routledge.

McNamara, T. F. (1998). Policy and social considerations in language assessment. In DR Hall and A Hewings (Eds.), Innovation in English language teaching. Oxon: Routledge.

McCarthy, M. \& Carter (2001). Designing the discourse syllabus. Oxon: Routledge.

McKay, S. L. (2003). EIL curriculum development. Cambridge: Cambridge University Press.

Nunan, D. \& Lamb, C. (2001). Managing the learning process. Oxon: Routledge.

Nunan, D. (2001). Teaching grammar in context. In Candlin\& N Mercer (Eds.), English language teaching in its social context. London: Routledge.

Richards, J. C. (2001). Course planning and syllabus design. Cambridge: Cambridge University Press.

Taylor, L. (2005). Washback and impact. Oxford: Oxford University Press. 